\title{
WHO DOES THE CRIMINAL POLICY IN ROMANIA?
}

DOI: 10.47743/rdc-2019-1-0005

Tudorel TOADER

Professor PhD, Rector

"Alexandru Ioan Cuza" University of Iași

ttoader@uaic.ro
Marieta SAFTA

PhD Associate Professor, "Titu Maiorescu" University of Bucharest, Faculty of Law

First assistant magistrate, Constitutional Court of Romania

marieta.safta@ccr.ro

\section{Abstract}

The study approaches the legal side of criminal policy with respect to the national constitutional framework, in which context il will be examined the competence to legislate, the institutional actors involved in the process of lawmaking and the constitutional limits of the legislation in criminal matters, in order to answer, mainly, to the title question and, in the alternative, to the question regarding how the criminal law must be achieved in accordance with the constitutional requirements.

Keywords: criminal policy, constitutional review, the principle of legality in the criminal law

\section{Introduction}

Criminal policy has been defined as a set of political choices made by the State in order to determine, orient and put into action the "power to punish" over which it has a monopoly ${ }^{1}$. It has also been shown that, in its most general sense, criminal policy concerns, on the one hand, an analysis of the means put in place to prevent and combat crime, and, on the other hand, an action based on economic and social choices to respond to prevention, control and resocialization issues, effectively and fairly ${ }^{2}$. From a

1 E. Fortis, Politique criminelle, in Traite international de droit constitutionnel, coordinated by M. Troperand Dominique Chagnollaud, Tome 3, Dalloz, 2012, p. 707.

2 Politique criminelle - G. Lopez, S. Tzitzis (dir), Dictionnaire des sciences criminelles, Paris, Dalloz, 2004, p. 716, apud E. Fortis, cited work, p. 708. 
legal point of view, which we have in mind here, the criminal policy is expressed by the rules which, in a broad sense, make up substantial criminal law and procedural criminal law.

Approaching the competence to carry out the criminal policy implies a much broader general context, respectively of the principle discussions regarding the content and the significance of the criminal policy, of the legitimacy of realizing such a policy, of the developments registered in the field. The doctrine deals with this subject in relation to the concept of sovereignty of the State, trying to answer, among others, questions such as in whose name someone is called to be criminally responsible and what are the limits of this responsibility, respectively the limits of criminal law and of criminality.

As far as we are concerned, we will approach the legal side of criminal policy with respect to the national constitutional framework, in which context we will examine the competence to legislate, the institutional actors involved in the process of lawmaking and the constitutional limits of the legislation in criminal matters, in order to answer, mainly, to the title question and, in the alternative, to the question regarding how the criminal law must be achieved in accordance with the constitutional requirements.

\section{Lawmaking in criminal matters}

\section{The competence of the Parliament versus the competence of the Government in the adoption of regulations in criminal matters}

The Constitution establishes the competent authorities and the principles applicable to the lawmaking in the criminal field, subsumed to the general principle of legality. In this respect, Article 73 (3) h) of the Constitution provides that "The organic law shall regulate the criminal offences, penalties, and the execution thereof", and para. (3) letter i) of the same article provides that, "The organic law shall regulate the granting of amnesty or collective pardon". Therefore, it follows that the incrimination/decriminalization of certain facts or reconfiguration of the constituent elements of an offense is carried out by organic law, therefore by the Parliament which, according to Article 61 (1) of the Constitution, is the supreme representative body and the only legislative authority of the State.

However, the Constitution also regulates the legislative delegation, in Article 115, a concept that allows, in the situations strictly regulated by the constitutional text of reference, the Government to act as delegated legislature. Distinguishing in this respect the concept of "law", the Constitutional Court ${ }^{3}$ held that it has more meanings depending on the distinction between the formal and the material criterion. According to the first criterion, the law is characterized as an act of the legislative authority,

${ }^{3}$ See also Constitutional Court, Decision no. 146/2004, Official Gazette, Part I, no. 416 of 10 May 2004.

\section{CONSTITUTIONAL LAW REVIEW}


identifying itself by the body called to adopt it and by the procedure to be followed for this purpose. This conclusion results from the corroboration of the provisions of Article 61 (1) the second thesis of the Constitution, according to which "Parliament is [...] the only legislative authority of the country", with the provisions of Article 76, Article 77 and Article 78, according to which the law adopted by the Parliament is subject to promulgation by the President of Romania and enters into force three days after its publication in the Official Gazette of Romania, Part I, if its content is not provided for at a later date. The material criterion considers the content of the regulation, being defined taking into account the object of the norm, respectively the nature of the regulated social relations. As concerns the Government ordinances, the Court held that, by elaborating such normative acts, the administrative body exercises a competence by attribution which, by its nature, falls within the legislative competence of the Parliament. Therefore, the ordinance is not a law in a formal sense, but an administrative act in the field of law, assimilated to it by the effects it produces, observing in this respect the material criterion. Consequently, since a normative legal act, in general, is defined both by form and content, the law in a broad sense, thus also including assimilated acts, is the result of combining the formal criterion with the material one. Thus, in view of its case-law, the Court held that the Government's ordinances and emergency ordinances, in material terms, contain primary regulatory rules, having a legal force assimilated to that of the law.

With regard to the subject analyzed here, we find that, according to the provisions of Article 115 of the Constitution, the prohibition to regulate in the field of organic law concerns only the ordinances issued under a law of empowerment, and not the emergency ordinances of the Government. Therefore, it follows that the Government would have the power to legislate in the field of substantial criminal law, in compliance with the requirements imposed by Article 115 (6) of the Constitution ${ }^{4}$. But we have expressed and support the opinion that "emergency ordinances are publicly perceived as a factor of legal uncertainty, especially in criminal matters, that, even more so, for the future, a strict interpretation of the constitutional framework that forms the legislative delegation is required, as well as a careful and detailed explanation, within the acts to be adopted, of the grounds that determine the use of the instrument of the emergency ordinance, and of its incorporation in the constitutional text of reference" 5 .

Confirming the ones shown regarding the public perception, the national referendum of 26 May 2019, initiated by the President of Romania revealed the majority popular will in the sense of the agreement with "the prohibition of the adoption by the Government of the emergency ordinances in the field of crime,

4 "Emergency ordinances cannot be adopted in the field of constitutional laws, they cannot affect the regime of the fundamental institutions of the State, the rights, freedoms and duties provided for by the Constitution, the electoral rights and they cannot aim at measures of forced transfer into public property."

${ }^{5}$ https://europunkt.ro/2017/06/07/interviu-marieta-safta-secretar-de-stat-la-ministerul-justitiei-con servarea-caracterului-de-exceptie-al-legiferarii-pe-calea-delegarii-legislative-incumba-deopotriva-parlamentu lui-si-guvernului/

CONSTITUTIONAL NEWS 
punishment and judicial organization and with the extension of the right to challenge the ordinances directly to the Constitutional Court". Taking into account the recitals of the CCR's ruling ${ }^{6}$ by which it stated that "such a referendum (...) may lead to a refrain from regulating in a way contrary to the will expressed by the voters", we consider that the Government should show an attitude of abstention from regulating emergency ordinances in the field of crime and punishment. Moreover, as a result of this referendum, an initiative for the revision of the Constitution was promoted, aiming at including the amendment of Article 115 of the Constitution, in the sense that "the emergency ordinances cannot be adopted in the field of organic laws having the regulatory object provided for by Article 73(3) h), i) and I)", therefore including as concerns "the offences, the penalties and the regime of their execution". In the decision pronounced on this initiative for the revision ${ }^{7}$, the Court also recalled the legislative proposal for the revision of the similar Constitution, initiated in 2014, when it was found that such a normative solution does not violate the limits of the revision of the Fundamental Law.

In the process of lawmaking, other legal subjects are involved, with competences regarding the initiation, debate, endorsement and promulgation of the normative acts, to which we will refer in the next section.

\section{Other legal subjects involved in the process of lawmaking in criminal matters}

\subsection{Legislative initiative}

According to Article 74 (1) of the Constitution, the legislative initiative belongs to the Government, the parliamentarians as well as the citizens, and, as regards the latter, the constitutional text establishes both conditions of exercise and limits. Thus, according to Article 74 (2) of the Constitution, amnesty and pardon may not be the object of the citizens' legislative initiative.

Constitutional rules being of strict interpretation, it is obvious that this right cannot be exercised by any other person/entity, such as, for example, a Parliamentary Commission. In this regard, the Constitutional Court (CCR) held that "in principle, the elaboration does not mean that the Special Commission itself initiates the legislative project/proposal, because it has no right of legislative initiative" ${ }^{\prime 2}$. Although the Commission consists of deputies and senators - parliamentarians who, by virtue of their constitutional role, have the right of legislative initiative, the thesis according to which the right to legislative initiative, proper to the members of the Commission, seen as ut singuli, cannot be accepted. It can be extended to the Commission itself, as the internal working body of the Parliament, because the latter has its own identity, different from

${ }^{6}$ Resolution no. 2/2019, unpublished, available on the website of the Constitutional Court, www.ccr.ro.

${ }^{7}$ Decision no.464/2019, Official Gazette no. 646 of 05 May 2019.

${ }^{8}$ See Decision no. 474/2016, Official Gazette, Part I, no.590 of 3 August 2016, paragraph 36. 
that of its parliamentary members and is not among the subjects of law listed expressly and limiting to Article 74 (1) of the Fundamental Law. Nor can the consideration that the work of a parliamentary committee be preparatory, without imposing a definitive vote or political will before the Parliament, cannot constitute a valid argument that extends, beyond the constitutional framework, the scope of the subjects of legislative initiative.

As concerns the Government, we note that its role is established by the provisions of Article 102 (1) of the Constitution, according to which "the Government shall, in accordance with its government program accepted by Parliament, ensure the implementation of the domestic and foreign policy of the country, and exercise the general management of public administration". The exercise of this role by the Government implies its involvement, within the limits and conditions provided for by the Constitution and Law no. 90/2001 regarding the organization and functioning of the Romanian Government and the ministries ${ }^{9}$, in the procedure of initiation, elaboration, endorsement, adoption of the draft normative acts, without these attributions being capable of determining a violation of the constitutional role of the Parliament but, on the contrary, of contributing, in conditions of constitutional loyalty, to the accomplishment of the Parliament's fundamental duty, namely the legislative duty. The Government must therefore fulfil its complementary competences in the elaboration of criminal law, as a whole and specifically through the competent ministries.

The Ministry of Justice has an essential role in this framework, which has among its main duties the one regarding the elaboration of public policies, strategies and action plans in the field of justice, of preventing and combating corruption and serious forms of crime, including in accordance with the objectives of the government program [Article 5 a) of the Government Resolution no. 652/2009 on the organization and functioning of the Ministry of Justice ${ }^{10}$ ]. According to Article 6 section II 1 and 2 of the same normative act, the Ministry of Justice has among its duties: the constitution, according to the law, of the commissions for the elaboration of the draft codes and other complex normative acts that concern the field of justice, being authorized, exclusively, to edit and publish their official editions, elaboration of draft normative acts related to its field of activity, participation in the support of draft laws within the parliamentary committees and in the plenary of the two Chambers. Significant are from the point of view of the analyzed subject the duties of the Ministry of Justice in the matter of supervision of the execution of the punishments, respectively the coordination of the activity of the probation system and of the penitentiary system; coordinating the execution of punishments, educational measures and other measures deprived or not of liberty and ensuring the conditions for observing the rights of the persons to whom such penalties or measures have been disposed (Article 6 section IV of the same normative act). According to Article 7 of the Government Resolution

\footnotetext{
${ }_{9}^{9}$ Published in the Official Gazette, Part I, no. 164 of 2 April 2001.

${ }^{10}$ Published in the Official Gazette, Part I, no. 443 of 29 June 2009.
} 
no. 652/2009, "in the exercise of its powers, the Ministry shall adopt a policy of institutional collaboration with the other ministries and specialized bodies of the central public administration, with the SCM, the Public Ministry, the National Union of Bars in Romania, The National Union of Public Notaries in Romania, the National Union of Judicial Executors, as well as with other public authorities, with the associations of judges and prosecutors and with other professional associations or non-governmental organizations, while preserving its objectives and policies in the field of competence".

In this context, we consider it important to emphasize that the legislation in force practically ensures the possibility of any subject of law interested in expressing itself and thus contributing to the accomplishment of criminal policy and legislation, distinct from the citizens' legislative initiative. Thus, Law no. 52/2003 on the transparency of decision-making in the public administration ${ }^{11}$ establishes in this regard the procedural rules applicable to ensure the transparency of decision-making within the central and local public administration authorities, elected or appointed, as well as of other public institutions using public financial resources, in the relations established between them and the citizens and their legally constituted associations, including in order to achieve the active participation of citizens in the administrative decision-making process and in the elaboration of normative acts. The principles underlying this law are to inform in advance, ex officio, the persons on the issues of public interest to be debated by the authorities of the central and local public administration, as well as on the draft normative acts, the consultation of the citizens and the legally constituted associations, at the initiative of public authorities, in the process of drafting normative acts; active participation of citizens in making administrative decisions and in the process of drafting normative acts, in compliance with the rules provided for by law.

\subsection{Endorsement of criminal law}

According to Article 9 (1) of Law no. 24/2000 on the norms of legislative technique for the elaboration of normative acts" "In the cases provided for by law, in the phase of elaboration of the draft normative acts, the initiator must request the endorsement of the authorities interested in their application, depending on the object of the regulation". Likewise, according to Article 9 (2) of the same normative act, "After their elaboration and the conclusion of the endorsement procedure provided for in para. (1), the draft laws, the legislative proposals, as well as the draft ordinances and normative decisions of the Government are subject to the endorsement of the Legislative Council."

As concerns the authorities "interested in the application of criminal law", we note the case-law developments regarding the role of the Superior Council of Magistracy $(S C M)$, as it results from the corroboration of the general norm mentioned above with

${ }^{11}$ Republished in the Official Gazette, Part I, no. 749 of 3 December 2013.

12 Republished in the Official Gazette, Part I, no. 260 of 21 April 2010. 
Article 38 (3) of Law no.317/2004 regarding the Superior Council of Magistracy ${ }^{13}$, according to which "the Plenum of the Superior Council of Magistracy endorses the draft normative acts regarding the activity of the judicial authority" and Article 32 (1) of the same normative act, according to which "In cases where the law provides the opinion, approval or agreement of the Superior Council of Magistracy, the point of view issued by it is mandatory. If the law provides for the consultation or the opinion of the Superior Council of Magistracy, the point of view issued by it is not mandatory".

Thus, the CCR noted that this competence [A/N of endorsement] of the Superior Council of Magistracy is a legal one, granted by the will of the Parliament on the basis of the constitutional text of Article 134 (4), according to which "the Superior Council of Magistracy also fulfils other duties established by its organic law, in fulfilling its role as guarantor of the independence of justice". Although the constitutional norm, expressing the role of guarantor of the independence of justice of the Superior Council of Magistracy, does not make any express reference to the obligation of the initiators of the draft normative acts to request the endorsement of this authority, the endorsement of the draft normative acts regarding the activity of the judicial authority is treated in the law of organization and functioning of the Superior Council of Magistracy, to which the fundamental Law refers. However, the Court has circumscribed the scope of the phrase "normative acts concerning the activity of the judicial authority", according to which the legal and constitutional obligation of the competent authorities to request the opinion of the Superior Council of Magistracy can be determined. In the recitals of Decision no. 901 of 17 June 2009, published in the Official Gazette of Romania, Part I, no. 503 of 21 July 2001, the Constitutional Court held that the phrase refers "only to the normative acts that directly concern the organization and functioning of the judicial authority, such as the functioning of the courts, the careers of the magistrates, their rights and obligations, etc., in order not to reach the distortion of the role of the Superior Council of Magistracy". As a consequence, by Decision no. 3 of 15 January 2014, the Court found that the draft laws implying an opinion given by the Council are the normative acts regarding the status of judges and prosecutors (which include provisions regarding the rights and duties of judges and prosecutors, incompatibilities and prohibitions, appointment, promotion, suspension and termination of the office of judge or prosecutor, delegation, secondment and transfer of judges and prosecutors, their responsibility, etc.), currently regulated by Law no. 303/2004, judicial organization (courts - organization/competences/management, the Public Ministry - organization/ competences/management, the organization and functioning of the National Institute of Magistracy, the specialized auxiliary compartments within the courts and prosecutor's offices, the budgets of the courts and prosecutor's offices, etc.), currently regulated by Law no. 304/2004, as well as the normative acts regarding the organization and functioning of the SCM, with the inner of the matter in Law no. 317/2004. The

${ }^{13}$ Republished in the Official Gazette, Part I, no. 628 of 1 September 2012.

CONSTITUTIONAL NEWS 
Court ruled that "any other interpretation given to the phrase normative acts regarding the activity of the judicial authority would cause an extension of the competences of the Superior Council of Magistracy that would not be based on clear and predictable criteria, so it would be arbitrary". The Court's conclusion, expressed in the same decision, is that by accepting the claims "according to which the failure to submit to the Council's approval the normative act by which amendments to the Criminal Code are brought would contravene its constitutional role of guarantor of the independence of justice, the thesis would be implicitly accepted according to which the request of the opinion of the Superior Council of Magistracy would be obligatory in the elaboration of all normative acts. To the extent that any law is liable to generate a dispute situation, which would determine the investing of a court of law with the settlement of the dispute, it could be concluded that all the normative acts concern the activity of the judicial authority. Or, beyond the lack of logical and legal basis for such an interpretation, the created circumstance would lead to the situation in which the Superior Council of Magistracy would fulfil competences similar to those of the Legislative Council, which according to Article 79 (1) of the Constitution «it is a specialized consultative body of the Parliament, which endorses the draft normative acts in order to systematize, unify and coordinate all the legislation", which is inadmissible. The Superior Council of Magistracy, as a component part of the judicial authority, according to the provisions of the Fundamental Law, with the role of guarantor of the independence of justice, cannot be transformed into an advisory body of the Parliament, the primary legislative authority, [or the Government, delegated legislative authority, editor's note], without affecting constitutional values such as the rule of law or the principle of separation and balance of powers within constitutional democracy"14. As a result "in view of the established case-law of the constitutional court", the Court held that "the Government has no constitutional or legal obligation to seek the opinion of the Superior Council of Magistracy in matters other than the activity of the judicial authority, and the Superior Council of Magistracy does not have the legal power to issue such an opinion" 15 .

With regard to other authorities of constitutional rank with powers of opinion, and, in itself, the lack of request or the existence of opinions in the procedure of elaborating normative acts, we note that they have been qualified by the Court as aspects regarding the observance of the legal obligations of the authorities involved in this procedure and, implicitly, as aiming at an unconstitutionality of the normative acts,

14 Decision no. 63 of 8 February 2017 regarding the requests for the settlement of legal disputes of a constitutional nature between the executive authority - the Government of Romania, on the one hand, and the legislative authority - the Parliament of Romania, on the other, as well as between the executive authority - the Romanian Government, on the one hand, and the judicial authority - the Superior Council of Magistracy, on the other hand, requests made by the president of the Superior Council of Magistracy, respectively by the President of Romania, published in the Official Gazette, Part I, no. 145 of 27 February 2017, paragraphs 102-105.

15 Ibidem, paragraph 107.

CONSTITUTIONAL LAW REVIEW 
which can be analyzed under the conditions of Article 146 a) and d) of the Constitution $^{16}$. The Constitutional Court has ruled that the lack of opinion of the public authorities involved does not automatically lead to the unconstitutionality of the law on which it was not given, because what prevails is the obligation of the Government to request it. The fact that the authority which is required to issue such an opinion, although requested to do so, has not fulfilled this duty "constitutes a misunderstanding of its legal and constitutional role, but without affecting the constitutionality of the law on which the opinion was not given"17.

Regarding the approval by the Legislative Council, this constitutes a mandatory phase in the lawmaking procedure. As a specialized consultative body of the Parliament, the Legislative Council endorses all the draft normative acts in order to systematize, unify and coordinate the entire legislation and which keeps the official record of the Romanian legislation. Also, according to Article 10 (3) and (4) of the same law: "The opinion of the Legislative Council is a specialized opinion and has an advisory character. (4) The observations and proposals of the Legislative Council regarding the observance of the norms of legislative technique will be considered when finalizing the draft normative act. Their non-acceptance must be motivated in the presentation of the project or in an accompanying note." We also note the jurisprudential developments in the sense that "the opinion of the Legislative Council can be requested not only at the beginning of the legislative process, but also in the parliamentary procedure", with reference to Article 66 of the Regulations of the Chamber of Deputies which states that: "At the meetings of the commission notified, the rapporteurs of the commissions notified for opinions, as well as specialists of the Legislative Council will be invited, if their presence is necessary", and Article 99 (7) of the same Regulation, according to which "The chairman of the commission referred to may request the opinion of the Legislative Council regarding some amendments, a point of view which will be sent within the term set by the commission". Likewise, Article116 of the Regulations of the Senate stipulates that "In the case of the draft laws and the legislative proposals received from the Chamber of Deputies, if substantial amendments were made to the initial draft, the chairman of the standing commission notified may request the Permanent Bureau to request a new opinion of the Legislative Council". At the same time, Article 2 (1) b) of the Law no. 73/1993 provides that the Legislative Council "analyzes and approves, at the request of the chairman of the parliamentary commission notified, the amendments subject to the debate of the commission and the draft laws." As far as we are concerned, the opinion of the Legislative Council and during the legislative procedure would give expression to the proper use of this concept

${ }^{16}$ Ibidem, paragraph 108.

${ }^{17}$ See Decision no. 383 of 23 March 2011, published in the Official Gazette, Part I, no.281 of 21 April 2011, paragraph I.3, Decision no. 574 of 4 May 2011, paragraph I.2, and Decision no. 575 of 4 May 2011, paragraph IV.A.2., published in the Official Gazette, Part I, no. 368 of 26 May 2011.

CONSTITUTIONAL NEWS 
in achieving the objective imposed by Article 1 (5) of the Constitution, respectively a quality legislation, which complies with all the norms of legislative technique for the elaboration of normative acts.

\subsection{Debate, adoption and promulgation of criminal law}

The debate and the adoption of criminal law in Parliament is subject to the requirements common to the organic laws regarding the principle of bicameralism, the procedure of amendments and voting, so that we will not insist on this.

However, we note parliamentary practices such as the establishment of the special joint commission of the Chamber of Deputies and the Senate for the systematization, unification and assurance of legislative stability in the field of justice ${ }^{18}$, for the purpose of amending/supplementing the Criminal Code/Criminal Procedure Code/laws in the field of justice. As noted by the CCR itself, the establishment of such a Commission does not violate the provisions of the Constitution and may have a positive role, meaning that "a special joint commission can more effectively achieve its proposed objective through direct cooperation between deputies and senators, materialized both by the elaboration of own proposals and by the reunification of the legislative projects/proposals that are in different phases of the parliamentary procedure. Moreover, it is not possible to dissipate the parliamentary effort by the simultaneous or successive submission of other projects/legislative proposals, which might contain parallel/antithetical provisions, which, thus, could affect the unity of the parliamentary effort to elaborate a coherent, complete and unitary legislative proposal regarding the respective law"19. However, we underline the risks that can be delayed by certain projects necessary to be adopted quickly, such as those of transposition of European directives or of agreeing the criminal law with the decisions of the Constitutional Court. Special commissions such as the one mentioned, by their very nature, are intended for complex approaches, assuming broad and inherently disputed amendments to the legislation, and not punctual amendments and considered as urgent. We believe that in order to ensure the effectiveness of the criminal justice system and to observe the commitments assumed as a member state of the European Union, the legislative proposals by which the criminal law is agreed with the decisions of the constitutional court or by transposing acts of the European Union should be treated separately and with appropriate celerity ${ }^{20}$, in order to avoid the negative consequences of violating European norms.

The stage of the promulgation of the law by the President of Romania implies, implicitly, its possibility to send the law of Parliament, for review, and/or to notify the

${ }^{18}$ Resolution of the Parliament of Romania no. 69/2017, Official Gazette no. 776 of 29 September 2017.

${ }^{19}$ Decision no. 828/2017, Official Gazette no. 185 of 28 February 2018.

20 https://europunkt.ro/2017/06/07/interviu-marieta-safta-secretar-de-stat-la-ministerul-justitiei-con servarea-caracterului-de-exceptie-al-legiferarii-pe-calea-delegarii-legislative-incumba-deopotriva-parlamentu lui-si-guvernului/. 
Constitutional Court for its constitutional review. In this way, even if he has no legislative initiative or any role in the procedure for the election debate, the President of Romania interferes/influences the adoption of normative acts, including in the criminal field. Under this aspect, interpreting the provisions of Article 77 (2) of the Constitution, according to which "Before promulgation, the President of Romania may return the law to Parliament for reconsideration, and he may do so only once", the CCR noted that the President, during the promulgation procedure, has the obligation to analyze the normative content of the law and to ascertain if the regulatory, constitutional or conventional provisions to which Romania is a party have been complied with or if the public interest, social, economic or political realities justify the regulation adopted by the Parliament and subject to promulgation. Therefore, the President's analysis may concern, on the one hand, legality issues, deficiencies of the law related to the adoption procedure or its content by reference to existing domestic or foreign normative acts, and, on the other hand, opportunity issues which concern the economic, social, environmental, legislative and budgetary effects produced by the regulations adopted, the legislature being obliged to substantiate the solutions contained in the law, based on public policy documents approved by Parliament or Government [see also Article 6 (4) of Law no. 24/2000]. The reconsideration may be requested only once, for any reason - by form/procedure or substance/content, regarding the law in its entirety or for some of its rules. Following the wording of the request for reconsideration, the law shall be sent back to the Parliament, which is obliged to resume the lawmaking procedure and to debate in the plenum of the two Chambers the requests addressed by the President ${ }^{21}$.

As concerns the constitutional review of the criminal norms, we shall treat it in a separate section, considering its importance in the subject analyzed.

\section{The constitutional review of the criminal law. Constitutional limits}

\section{of lawmaking in criminal matters}

\section{The role and competence of the Constitutional Court in this matter}

An increasingly important role in the configuration/reconfiguration of criminal law rests with the Constitutional Court ${ }^{22}$. In this regard, we shall remind that the

21 Decision no. 30/2016, Official Gazette no. 117 of 16 February 2016.

${ }^{22}$ And other constitutional litigation courts that have assumed the role of review / interpreter of criminal policy; for example, the doctrine mentions the French Constitutional Council which issued "genuine criminal policy directives addressed to the judicial authority" in the constitutional review of a law of 2004 - see C. Lazerges, Le Conseil constitutionnel acteur de la politique criminelle, RSC 2004, 725, apud E. Fortis, Politique criminelle, in Traite international de droit constitutionnel, coordinated by M. Troper, D. Chagnollaud, Tome 3, Dalloz, 2012. 
constitutional court does not adopt rules, does not rule on their opportunity, but determines whether the rules adopted by Parliament are in accordance with the fundamental law. In an established case-law, the Constitutional Court has ruled in the sense that "it rules on the constitutionality of a law or ordinance or a provision of a law or ordinance in force, which means their analysis in relation to the provisions or principles of the Constitution. This is a legal analysis and the Court does not have the possibility to sanction the opportunity or the efficiency of the economic policy adopted by the State. The same conclusion is also required on the criticism of unconstitutionality regarding the inefficiency and incoherence of the policy adopted by the legislature, which failed to achieve the proposed objectives" ${ }^{23}$. Likewise, it "does not fall within its competence to rule on the judgments, some of which have no legal character, regarding whether the law subject to constitutional review can achieve the purpose for which it was initiated and adopted, and even if, eventually, such appraisals would be justified. The Constitutional Court does not decide whether a law is good or not, whether it is effective or not, or whether it is appropriate or not. Only the Parliament can decide, within the limits provided in the Constitution, on the content of the legal regulations and the opportunity for their adoption. Moreover, the rule of law, whose existence is regulated by Article 1 (3) of the Fundamental Law, requires the recognition by each power of the acts and measures taken by the other powers within the limits provided by the Constitution" 24 .

Therefore, the Constitutional Court does not have the power to assume itself the criminal policy of the State ${ }^{25}$ but it is competent "to censure the option of the legislature if it does not comply with the constitutional principles and requirements" 26 . Thus, according to the Constitutional Court of Romania, "the intervention of the Court is legitimate only insofar as the capacity of the State to combat the criminal phenomenon is affected or the fundamental rights and freedoms are not observed"27. The "intervention" shall be accomplished within the limits of the powers and competence of the Constitutional Court, and with the use of the constitutional review toolkit. Further, we will look at some points in this regard, first on the extrinsic constitutionality issue of criminal law, then on the intrinsic one.

23 Decision no. 172 of 19 March 2015, published in the Official Gazette, Part I, no. 336 of 18 May 2015.

${ }^{24}$ Decision no. 203 of 29 November 1999, published in the Official Gazette Part I, no. 603 of 9 December 1999, whose recitals mentioned in Decision no. 904 of 25 October 2012, published in the Official Gazette, Part I, no. 4 of 3 January 2013, invoked itself in Decision no. 172 of 19 March 2015, published in the Official Gazette Part I, no. 336 of 18 May 2015.

${ }_{25}$ Decision no. 650/2018, cited above.

26 See, in this regard, Decision no. 824/2015, Official Gazette, Part I, no. 122 of 17 February 2016, Decision no. 62 of 18 January 2007, published in the Official Gazette, Part I, no. 104 of 12 February 2007, or Decision no. 363 of 7 May 2015, published in the Official Gazette, Part I, no. 495 of 6 July 2015.

${ }^{27}$ Decision no. 650/2018, cited above. 


\section{Constitutional limits of lawmaking in criminal matters}

\subsection{Extrinsic constitutionality of criminal law}

A first issue in this regard could be the level of regulation. We have already established that the plenitude of competence regarding the lawmaking in criminal matters belongs to the Parliament, and the instrument used is that of the organic law. A distinct discussion in this context could concern the constitutional regulation of this area. Recently, the CCR analyzed two initiatives for the revision of the Constitution which raised elements of criminal policy, respectively of regulation in the field of substantial criminal law, at the level of constitutional rules. The Court held, among other things, that "the envisaged normative solution is rather of the law level". In this regard, by Decision no. 80 of 16 February 2014, para. 74, the Court ruled that "the level of detail of the constitutional principles must be a minimum one, this task resting with the lower normative acts. Moreover, too detailed regulation of a domain/social relationship has the effect of instability of the constitutional text. In this regard, the European Commission for Democracy through Law (Venice Commission) has shown that "the need for amendment in a given system is dependent on the length and level of detail of the constitutional text». The more detailed the constitutional text is, the more it is identified with the ordinary legislation and the more it is exposed to relatively frequent amendments (see the Report on the revision of the Constitution, adopted by the Venice Commission to the second $81^{\text {st }}$ plenary session, 11-12 December 2009)". Likewise, the Court noted that "In the light of the public perception, it is noteworthy that the seriousness of the social danger of the various categories of crimes over time supports fluctuating assessments, which means that the public perception of the seriousness of the crime committed has its own dynamics. As a result, the exclusion de plano by constitutional regulation of corruption offences from the possibility of individual pardon, thus lacking the competent authority to assess their seriousness, danger and social impact on a case-by-case basis, can create obvious discrimination situations and undermine the authority of the State precisely in the exercise of certain public prerogatives in favour of the citizens. It is true that at one point in the evolution of the society it can be appreciated - even on the advisory referendum, such as the one of 26 May 2019 - that no individual pardons should be granted in respect of all or certain offences, but such an assessment takes into account the need to abstain from the competent authority to exercise the discretionary power it enjoys in these areas, and by no means to limit its discretionary power conferred by the Constitution itself. Therefore, the analysis of opportunity and political responsibility rests with the institution vested by the Constitution with the power of granting individual pardon, through a case-by-case analysis" 28 .

Another topic of analysis, on the extrinsic constitutionality component of the criminal law concerns the observance of the constitutional requirements of the

${ }^{28}$ Decision no. 465/2019, Official Gazette no. 645 of 05 August 2019.

CONSTITUTIONAL NEWS 
lawmaking procedure. The role of these norms was recently emphasized by the CCR, which noted that "within the constitutional norms, the provisions that include procedural rules incident to the legislation matter are correlated and are subsumed to the principle of legality, enshrined in Article 1 (5) of the Constitution, in turn this principle standing at the foundation of the rule of law, expressly enshrined in the provisions of Article 1 (3) of the Constitution. Moreover, the Venice Commission also notes, in the report entitled Rule of law checklist, adopted at the $106^{\text {th }}$ plenary session (Venice, 11-12 March 2016), that the procedure for adopting laws is a criterion in the assessment of the legality, which is the first of the reference values of the rule of law (point II A5). In this respect, among others, according to the same document, the existence of clear constitutional rules regarding the legislative procedure, the public debates of the draft laws, their adequate justification, and the existence of impact assessments before the adoption of the laws are relevant. Regarding the role of these procedures, the Commission notes that the rule of law is related to democracy by promoting responsibility and access to rights that limit the powers of the majority. In other words, the regulation of clear rules regarding the legislative procedure, including at the level of the Fundamental Law, and the observance of the rules thus established constitute a guarantee against the abuse of power of the parliamentary majority, therefore, a guarantee of democracy. To the extent that the rules on the legislative procedure are constitutionally enshrined, the Constitutional Court is competent to rule on the way in which the laws adopted by the Parliament comply with them and to properly sanction their infringement ${ }^{29}$. The Constitution of Romania contains express rules for all the procedural stages of the initiation, debate and adoption of laws in section 3 - Legislation, from Chapter I - Parliament, contained in title III - Public authorities, as follows: legislative initiative (Article 74), notification of the Chambers (Article 75), passing of bills and resolutions (Article 76), promulgation of laws (Article 77), entry into force laws (Article 78). Other procedural norms concern the approval of the normative acts, these being established, properly, in order to accomplish the constitutional role of some constitutional authorities such as the Legislative Council (Article 79), the Supreme Council of National Defence (Article 119), the Superior Council of the Magistracy (Article 133-134), the Economic and Social Council (Article 141). The amendment of the constitutional laws knows a distinct regulation in Title VII - Revision of the Constitution, where both the substantive and applicable conditions are stipulated."

We have set out particular elements regarding the legislative procedure, especially the approval, in the first part of the study, and regarding the compliance with the other requirements of constitutional procedure, these are common regardless of the regulatory area so we will not offer them a separate space in the present study.

${ }^{29}$ Decision no. 128/2019, Official Gazette, Part I, no.189 of 8 March 2019.

CONSTITUTIONAL LAW REVIEW 


\subsection{The intrinsic constitutionality of criminal law}

Regardless of the analyzed area, and even more in the criminal field, the legislation must observe the principle of legal certainty, enshrined in Article 1 (5) of the Constitution, according to which, "In Romania, the observance of the Constitution, its supremacy and the laws shall be mandatory". In applying this constitutional text and Article 1 (3) of the Constitution which establishes the rule of law, based on its recitals and the case-law of the European Court of Human Rights in the matter (ECHR), the CCR established a number of criteria that must be observed in the activity of legislation, consisting of: "precision, foreseeability and predictability so that the subject of law concerned can comply with its behaviour, so as to avoid the consequences of their non-compliance ${ }^{\prime 30}$. We have developed this topic with other priorities, keeping in mind the considerations of numerous decisions, by which the Court found that, "by the deficient way of drafting", the normative acts/provisions challenged do not comply with the legislative technical requirements specific to the legal norms, as provided by Law no. 24/2000 (with express reference to the above mentioned criteria) ${ }^{31}$.

The most spectacular developments regarding the constitutional review of the criminal norms, however, concern the configuration of the legislature's appreciation of the incrimination/decriminalization, on which the Constitutional Court has recently emphasized that "it is not and cannot be an absolute one. Thus, the [legislature] must, by his option, on the one hand, affect proportionally the individual freedom of the offender, taking into account the social relations disregarded by him, and, on the other hand, protect public order and safety, as well as the fundamental rights and freedoms of the other persons, taking into account the danger of the offender. Therefore, the State's criminal policy must be configured in such a way as to achieve a fair balance between competing interests; such a balance represents a guarantee associated with the rule of law"32. In its case-law, by circumventing this margin of appreciation, the Court has ruled both decisions that ascertained the unconstitutionality of the rules of incrimination and decisions that ascertained the unconstitutionality of the rules of decriminalization or relaxation of the sanctioning treatment.

Thus, as regards the first category of decisions, by which the Court sanctioned the infringement of constitutional principles and norms through criminal/procedural regulations, it contains numerous examples which we have referred to extensively in

${ }^{30}$ For example, Decision no. 61/2007, published in the Official Gazette, Part I, no.116 of 15 February 2007.

31 T. Toader, M. Safta, Constitutionalization of criminal law in Annals of the University of Bucharest-Law Series, supplement, 2014; T. Toader, M. Safta, The Constitutional Courts between the constitutional law and European law, report presented at the XVI-th Congress of the European Constitutional Courts Conference, "Cooperation among Constitutional Courts in Europe. Current situation and perspectives", Wien, 12-14 May 2014, http://www.vfgh.gv.at/cms/vfgh-kongress.

${ }^{32}$ Decision no. 650/2018, cited above. 
other studies ${ }^{33}$, and as a recent development, the use of the ultima ratio principle. The significance of the mentioned principle was explained in a series of decisions, the first of which was pronounced on the rules of incrimination of the abuse of office (including the abuse of office against the interests of the people, incriminated in the Criminal Code of $1969)^{34}$, by which the Court admitted the exception of unconstitutionality and found that the provisions of Article 246 of the Criminal Code of 1969 and of Article 297 (1) of the Criminal Code are constitutional insofar as the phrase "defective fulfilment" in their contents means "fulfilling by violation of the law". At the same time, regarding the abuse of office against public interests, incriminated in the previous criminal law, the Constitutional Court allowed the exception of unconstitutionality and found that the provisions of Article 248 of the Criminal Code of 1969 are constitutional insofar as the phrase "defective fulfilment" in their contents means "fulfilling by violation of the law $w^{\prime 35}$. Given that, in the basic version, both the offense of the abuse of office and the offense of negligence in office provide, as an identical normative way, the "defective fulfilment" of a duty of service, the Court has found that both the solution and the recitals of the aforementioned decisions, regarding the way of interpreting the phrase "defective fulfilment", are applicable mutatis mutandis also with regard to the offense of negligence in office ${ }^{36}$. Subsequently, both decisions were mentioned and resumed in cases with the same subject-matter, in which the Court ruled inadmissible decisions ${ }^{37}$. Recently, ruling in a priori review over the law as amended to comply with the decisions of the CCR, the Court found that the legislature did not reach this agreement, noting that, "in applying Decision no. 405 of 15 June 2016, the legislature should have been especially concerned with defining the intensity of the injury, with reference to the legitimate rights or interests of a natural or legal person, and not to establishing a derogatory value threshold itself, which, in reality, does not solve the issue of the ultima ratio character of the criminal sanction. Practically, by regulating the analyzed text, the

${ }^{33}$ See T. Toader, M. Safta, Constitutional legislative solutions enshrined in the Criminal Code of 2014, in the Constitutional Law Review, no. 4/2016, Universul Juridic Publishing House; T. Toader, M. Safta, Constitutional legislative solutions enshrined by the Criminal Procedure Code of 2014, in the Constitutional Law Review, no. 3/2016, Universul Juridic Publishing House, pp. 175-207, T. Toader, M. Safta, Constitutionalization of criminal law, in the Annals of the University of Bucharest - Law Series, supplement, 2014.

${ }^{34}$ Decision no. 405/2016, published in the Official Gazette, Part I, no. 517 of 8 July 2016.

35 Decision no. 392/2017, Official Gazette no. 504 of 30 June 2017.

${ }^{36}$ Decision no. 518/2017, Official Gazette no. 765 of 26 September 2017.

37 According to Article 29 (4) of Law no. 47/1992, the provisions found unconstitutional cannot be the subject-matter of the constitutional review; Decision no. 248/ 2017, Official Gazette no. 753 of 20 September 2017, Decision no. 383/2017, Official Gazette no. 866 of 2 November 2017, Decision no. 456 of 22 June 2017 , Official Gazette no. 818 of 17 October 2017, Decision no. 670/2017, Official Gazette no. 335 of 17 April 2018, Decision no. 858/2017, Official Gazette no. 340 of 18 April 2018, Decision no. 800/2017, Official Gazette no. 167 of 22 February 2018, Decision no. 552 of 13 July 2017, Official Gazette no. 886 of 10 November 2017, Decision no. 202 of 3 April 2018, Official Gazette no.613 of 17 July 2018, Decision no. 35 of 17 January 2019, Official Gazette no. 345 of 6 May 2019.

CONSTITUTIONAL LAW REVIEW 
same issues will persist regarding the difficulty of delimiting the various forms of liability, compared to the criminal one" 38 .

Thus, the CCR noted that the term comes from the Latin language, the phrase "ultima" comes from the Latin "ultimus" meaning "the last", and "ratio" has the meaning of "process", "method", "plan". Thus, ultima ratio has the common meaning of the final or final process or method used to achieve the goal pursued. The Court considered that, in criminal matters, this principle should not be interpreted as having the meaning that the criminal law should be regarded as the last measure applied from a chronological perspective, but it should be interpreted as having the meaning that the criminal law is the only one capable of achieving the intended purpose, other civil, administrative, measures etc. Being inappropriate in achieving this goal. In a broad sense, the purpose pursued by the legislature through the criminal law is to defend the order of law, and, in a restricted sense, is to defend social values, identified by the legislature in the special part of the Criminal Code, this purpose being, in principle, legitimate. At the same time, the measures adopted by the legislature to achieve the aim pursued must be adequate, necessary and observe a fair balance between the public and the individual interest. From the perspective of the "ultima ratio" principle in criminal matters, it is not enough to find that the incriminated facts affect the protected social value, but this infringement must have a certain degree of intensity, gravity, justifying the criminal sanction.

We note that the "ultima ratio" principle has no express constitutional enshrinement. Practically, the CCR received it by assimilating the European standards developed by international reference bodies such as the Venice Commission and the constitutional courts, in the application of Article 1 (5) of the Constitution which enshrines the principle of observing the Constitution, its supremacy and the laws, in correlation with the provisions of Article 61, regarding the role of the Parliament, and Article 1 (3) of the Constitution in the component regarding the rule of law. The Court also invoked "the right balance between the public and the individual interests", which corresponds to the principle of proportionality, also developed more recently in the case-law of the Constitutional Court ${ }^{39}$. In this way, by means of a compulsory case-law, the ultima ratio principle becomes not only a "principle of legislative ethics" 40 , but a true constitutional principle ${ }^{41}$, development of the principles of legality (clear, predictable, coherent legislation) and proportionality (by invoking the proportionality elements evoked by terms such as "gravity", "degree of intensity" of the injury caused by the act incriminated), subsumed to the exigencies of the rule of law.

${ }^{38}$ Decision no. 650/2018, cited above.

39 Thoroughly, M.M. Pivniceru, K. Benke, The Principle of Proportionality Reflected in the Case-Law of the Constitutional Court of Romania. German Constitutional Influences, Constitutional Law Review no. 1/2015 pp. 51-72.

${ }^{40}$ N. Jareborg, Criminalization as Last Resort (Ultima Ratio), Ohio State Journal of Criminal Law, vol. 2, no. 2/2005, 521-534.

${ }^{41}$ In this regard, see K. H. Tuori, cited work.

CONSTITUTIONAL NEWS 
Regarding the second direction of development of the case-law, in the sense of sanctioning the rules of discrimination, it initially aroused many criticisms, being reluctantly received and seen as the Court's departure from its traditional role as a negative legislature. Perhaps the best known decision ${ }^{42}$ of the CCR is the one that found the unconstitutionality of the decriminalization of insult and slander offenses. On that occasion, regarding the right of Parliament to decriminalize acts provided by the criminal law, the Court held that, "according to Article 1 (5) of the Fundamental Law, the observance of the Constitution is mandatory, where it follows that Parliament cannot exercise the power of incriminating and decriminalizing certain antisocial facts, except in compliance with the norms and principles enshrined in the Constitution. For example, the Parliament could not define and establish as offenses, without thereby violating the Constitution, facts in the content of which would include elements of discrimination between those provided by Article 4 (2) of the Fundamental Law. Likewise, the Parliament cannot proceed to eliminate the criminal legal protection of the values with constitutional status, such as the right to life, individual freedom, property right or, as in the case analyzed, human dignity". It was found, by the same decision, that "the freedom of regulation that Parliament has in these cases is exercised by regulating the conditions for taking criminal responsibility for antisocial acts that infringe the values provided and guaranteed by the Constitution".

Proof of the perception in Romania as "novelty" of such a solution for circumventing the margin of appreciation of the legislature in criminal matters, part of the Romanian courts of law did not give effectiveness to this decision, which resulted in promoting an appeal in the interest of the law and in pronouncing, even by the High Court of Cassation and Justice, a decision in contradiction with the ones stated by the CCR. Notified on the way of an exception of unconstitutionality with the examination of the constitutionality of Article $414^{5}$ (4) of the Code of Criminal Procedure, in interpreting the legal provisions regarding the appeal in the interest of the law that led, as it was shown, to the rejection of a decision of the Constitutional Court, the constitutional court found that "the release given to the legal issues settled" by the Decision of the High Court of Cassation and Justice - United Sections no. 8 of 18 October 2010, published in the Official Gazette of Romania, Part I, no. 416 of 14 June 2011, is unconstitutional, contravening the provisions of Article 1 (3), (4) and (5), of Article 126 (3), of Article 142 (1) and of Article 147 (1) and (4) of the Constitution and the Decision of the Constitutional Court no. 62 of 18 January $2007^{43}$. The Court ruled that, compared to the constitutional text of Article 126 (3), the phrase "the settlement given as to points of law", contained in Article $414^{5}$ (4) of the Code of Criminal Procedure, can only concern the interpretation and unitary application of the content of the legal provisions by the courts of law, and not the erection by the High Court of Cassation and Justice in the

42 Decision no. 62/2007, Official Gazette, Part I, no. 104 of 12 February 2007.

${ }^{43}$ Decision no. 206/2013, published in the Official Gazette, Part I, no. 350 of 13 June 2013.

CONSTITUTIONAL LAW REVIEW 
court of judicial review of Decision no. 62/2007 pronounced by the Constitutional Court. Such a precedent "seriously affects the legal certainty and the role of the Constitutional Court, it is necessary to sanction any interpretation of the provisions of Article $414^{5}$ (4) of the Code of Criminal Procedure, which regulates the obligatory nature of the settlements given as to points of law by the High Court of Cassation and Justice on the way of appeal in the interest of the law, in the sense that it would give this court the possibility that, in this way, under an unconstitutional norm, to give binding settlements that violate the Constitution and the decisions of the Constitutional Court".

The decisions subsequently issued by the CCR, by which it sanctioned the discrimination or relaxation of the sanctioning treatment of the offenses, no longer had the same retention as the Decision no.62/2007 (decision which, in itself, raised another controversial problem, respectively of the effects of the decisions. by which the Court finds the unconstitutionality of the abrogating norms). Thus, for example, by a recent decision ${ }^{44}$, the Court ruled in a priori review over several amendments to the Criminal Code, and found the unconstitutionality of the legislative amendments made regarding the provisions of Article 17 a) of the Criminal Code, in the sense of eliminating from their contents the variant of the commission of the criminal offense by omission, when there is a contractual obligation to act. The Court held that, by this amendment, the conventional obligation to act/intervene to prevent other forces from producing the incriminated result can no longer be the material element of the objective side of a crime and that, in the absence of such incrimination, the omission remains only a breach of a civil, social or moral obligation, without criminal significance, which determines the impossibility of undertaking criminal liability, for acts of murder, manslaughter, physical injury or physical injury through negligence, of many subjects of law which, by not fulfilling some obligations to do, resulting from the contracts concluded with the victims, in order to provide services, determines their death. Therefore, the analyzed legislative amendment significantly diminishes the preventive role of the provisions of Article 17 of the Criminal Code, with the consequence of the lack of criminal protection of the persons who enter into contracts similar to the ones analyzed above, in the aspect of protecting the right to life and to their physical and mental integrity. As the contractual relations as the aforementioned are extremely numerous and diverse, the analyzed legislative amendment lacks a very large number of legal subjects, which signifies the failure of the legislature to fulfil the obligation stipulated in Article 22 (1) of the Fundamental Law, that of guaranteeing the right to life, as well as the right to physical and mental integrity of the person. Such a diminution of the constraint force of the State is equivalent, according to the Court, with the violation of the positive obligations that result from Article 1 (3) of the Constitution, namely the establishment of a normative framework apt and able to protect the fundamental rights

${ }^{44}$ Decision no. 650/2018, cited above.

CONSTITUTIONAL NEWS 
and freedoms, including by using the means of criminal law when the social values harmed are of paramount importance.

By the same decision ${ }^{45}$, the Court found as unconstitutional the amendment of the way of regulating the concurrence of offenses in one action, noting that it represents an obvious relaxation of the sanctioning regime, compared to the one in force. The reasoning of the Court was one with a high degree of complexity, as it placed this measure in all the provisions of the Criminal Code corresponding to the criminal policy that was the basis for its elaboration. The Court held that although the legislature, in principle, has the constitutional power to establish such an orientation of the criminal policy, it must correlate the two axes it took into account when drafting the Criminal Code. Thus, if one wants the milder punishment of the concurrence of offences in one action, correlatively, the legislature has the constitutional obligation to increase the special penalty limits, in order to achieve a correlation between them. Otherwise, the offender would be encouraged to commit more crimes, because he knows that he is mainly punished for a single offense, and the increase applied under these conditions becomes insignificant. Under these circumstances, the Court finds that the State's criminal policy becomes contradictory: if initially this Criminal Code was intended to have a preventive function, in the expected form it is possible to encourage the commission of as many offenses as possible, because most of them remain unpunished. Such a conception "affects the foundation of the rule of law, as it is undeniable that criminal perseverance must be discouraged and severely punished". The Court concluded that this measure alters the criminal policy of the State, as it was promoted and standardized by the Criminal Code in force, trying to return to a formula established by the Criminal Code of 1969, distorting it, on the other hand, and thus, under the sanctioning treatment aspect, which affects the fundamental rights and freedoms as a whole, constituting not only a specific threat to a fundamental right or freedom, but to the rule of law, as enshrined in Article 1 (3) of the Constitution. Nothing prevents the legislature from amending/changing the criminal policy of the State, but this must be correlated with the overall conception of the Criminal Code and in accordance with the requirements of the Constitution; this means that the State ensures a fair balance between the protection of the individual freedom of the offender and the fundamental rights and freedoms of the other persons. Likewise, the Court found ${ }^{46}$ regarding certain offenses contained in a law with criminal provisions - the Law on the health of reproduction and medical assisted human reproduction - that they "do not fit in the criminal policy of the Parliament considered in the elaboration of the Criminal Code".

\footnotetext{
${ }^{45}$ Decision no. 650/2018, cited above.

${ }^{46}$ Decision no. 418 of 18 July 2005, Official Gazette no. 664 of 26 July 2005, Decision no. 650/2018, cited
} above.

CONSTITUTIONAL LAW REVIEW 
2.3. Distinctions regarding the obligations of the legislature as a result of the decisions of the Constitutional Court establishing the unconstitutionality of the laws before promulgation

We consider it is necessary to mention in this context, because we consider that it is likely to substantiate the distinction we have made (supra point II.2.3) regarding the procedure for adopting the laws that agree the legislation with the decisions of the CCR, the distinction that the Court has made, from the same perspective, regarding the effects of its decisions establishing the unconstitutionality of the laws before promulgation.

Thus, in principle, in its case-law, the CCR stated that, in the event that it finds the constitutionality of a law as whole and not just some provisions of it, "pronouncing such a decision has a definitive effect on that normative act, the consequence being the cessation of the legislative process regarding the respective regulation". At the same time, considering the provisions of Article 61 (1) of the Constitution, which establish that "Parliament is the supreme representative body of the Romanian people and the sole legislative authority of the country", the Court also noted the following: "The competence of its legislation on a certain area cannot be limited if the law thus adopted complies with the requirements of the Fundamental Law. Therefore, the legislature's option to legislate in the matter in which the Constitutional Court has allowed a notification of unconstitutionality regarding a law as a whole implies that all the phases of the legislative process provided by the Constitution and the regulations of the two Chambers of Parliament have been completed ${ }^{47 "}$. Likewise, the Court has established that the review, more specifically the agreement of the decision, applies only when the Court has found that its provisions are unconstitutional, and not when the unconstitutionality concerns the normative act as a whole, otherwise violating Article 147 (2) of the Constitution ${ }^{48}$. Therefore, in the event of the unconstitutionality of the law as a whole, the issuance of such a decision has a definitive effect on that normative act, the consequence being the cessation of the legislative process regarding the respective regulation. Parliament has the obligation to ascertain the legal cessation of the legislative process, as a result of the unconstitutionality of the law, in its entirety, and, in the event of the initiation of a new legislative action on the same regulatory area, to comply with those established by the decision of the Constitutional Court ${ }^{49}$.

${ }^{47}$ See, in this regard, Decision no. 308 of 28 March 2012, published in the Official Gazette, Part I, no. 309 of 9 May 2012, Decision no. 1 of 10 January 2014, published in the Official Gazette, Part I, no. 123 of 19 February 2014, Decision no. 619 of 11 October 2016, published in the Official Gazette, Part I, no. 6 of 4 January 2017, paragraph 50, or Decision no. 432 of 21 June 2018, published in the Official Gazette, Part I, no. 575 of 6 July 2018, paragraph 35.

${ }^{48}$ See, in this regard, Decision no. 581 of 20 July 2016, published in the Official Gazette, Part I, no. 737 of 22 September 2016, paragraphs 45-48.

${ }^{49}$ See, in this regard, Decision no. 76 of 30 January 2019, published in the Official Gazette, Part I, no. 217 din 20 March 2019, paragraph 42, Decision no. 139 of 13 March 2019, published in the Official Gazette, Part I, no. 336 of 3 May 2019, paragraph 88, Decision no. 140 of 13 March 2019, published in the Official Gazette, Part I, no. 377 of 14 May 2019, paragraph 86, or Decision no. 141 of 13 March 2019, published in the Official Gazette, Part I, no. 389 of 17 May 2019, paragraph 96.

CONSTITUTIONAL NEWS 
Applying this case-law of principle of the Constitutional Court regarding the effects of the decision to ascertain the unconstitutionality of a law as a whole to the specific situation of the laws transposing the decisions of the constitutional court, mandatory for the Parliament according to Article 147 (4) of the Constitution, the CCR held that "it is obvious that, in the event of ascertaining the unconstitutionality of such a law, in its entirety, the decision of the Court cannot have the effect of ceasing the legislative process regarding the respective regulation, as such a consequence attached to the judicial act would be liable to prevent the Parliament in fulfilling the constitutional obligation expressly provided by Article 147 (2). Moreover, the legislature cannot choose to abandon the legal procedure initiated, since, as mentioned, such an option would have the effect of keeping the legislative solution declared as unconstitutional by way of a posteriori constitutional review and, consequently, the lack of legal effects of the Court's decision that was the basis of the legislative amendment initiative. Therefore, in terms of the effects that the decision ascertaining the unconstitutionality of a law produces, as a whole, the specific difference between the law of transposition of the decisions of the constitutional court, declared unconstitutional as a whole, and the other types of laws, declared unconstitutional, as a whole, is given by the express regulation of Article 147 of the Constitution, which establishes to Parliament the obligation to ensure the constitutionalization of the legal norms, in accordance with the decisions of the constitutional court."

\section{Development of European criminal law. Consequences}

\section{in the policy/regulation plan in the criminal field}

In shaping the criminal policy, the development of European criminal law in a broad sense must also be taken into account, to which obliges the constitutional provisions of Article 148, as regards the European Union, and of Article 20, as regards the Council of Europe. The provisions of Article 148 of the Constitution of Romania provide, in para. (2), the priority of the provisions of the constitutive treaties of the European Union, as well as of the other Community regulations with mandatory character, as opposed to the provisions contrary to the internal laws, and in para. (4), the obligation of the Parliament, the President of Romania, the Government and the judicial authority to guarantee the fulfilment of the obligations resulting from the act of accession and from the provisions of para. (2). The provisions of Article 20 of the Constitution of Romania establish the supralegislative position of the international human rights treaties to which Romania is a party, their constitutional interpretative value, as well as their priority, unless the Constitution and internal laws contain more favourable provisions.

${ }^{50}$ Decision no. 467 of 29 July 2019, published in the Official Gazette, Part I, no. 765 of 20 September 2019.

\section{CONSTITUTIONAL LAW REVIEW}


In time, the use of the Convention for the defence of human rights and the case-law of the ECHR has become more and more substantial in the decisions of the Constitutional Court of Romania and, in recent years, the frequent invocation of the provisions of Article 148 of the Constitution, which raises the problem of legal relationships between the national legal order and that of the European Union, including regarding the rules of criminal law.

European criminal law has been suggestively characterized ${ }^{51}$ as "a kind of umbrella concept covering all those rules and practices of criminal law and criminal procedure law based on the provisions and actions of the European Union (European law in the narrow sense) and the Council of Europe (European law in the broad sense), and leading (or intending to lead) to the extended harmonization of national criminal (and criminal procedure) law". They are included here ${ }^{52}$ the legal provisions establishing sanctions applicable in all Member States, but also those which influence national criminal law in the sense of Europeanization (approximation of laws), the procedural elements meant to ensure the effectiveness of criminal law in the European Union, as well as the minimum guarantees regarding the criminal law derived from the interpretation of the Convention for the Protection of Fundamental Rights.

With special reference to the European Union framework, the specialized doctrine almost invariably points to the more sensitive issues raised by the criminal norms from the point of view of legal integration, by approximating or even identifying them with the core of national sovereignty. Therefore, the involvement of the European Union ${ }^{53}$ in criminal law has created significant challenges and tensions, but developments in this area continue, influencing the criminal policy of the Member States. As noted ${ }^{54}$, European rules may require Member States to set a minimum level of criminalization, in relation to the obligation to protect their legal interests, whether we are talking about financial, physical or human resources. In this regard, Article 4 (3) of the Treaty on European Union states that "Pursuant to the principle of sincere cooperation, the Union and the Member States shall, in full mutual respect, assist each other in carrying out tasks which flow from the Treaties. The Member States shall take any appropriate measure, general or particular, to ensure the fulfilment of the obligations arising out of the Treaties or resulting from the acts of the institutions of the Union. The Member States shall facilitate the achievement of the Union's and refrain from any measure which could jeopardize the attainment of the Union's objectives." As a result, Member States are obliged to lay down sanctions (where necessary, of a criminal nature), in order to ensure the protection of the legal interests of the Union.

From this perspective, the Court of Justice of the European Union (CJEU) and in particular the mechanism for preliminary rulings functions as a true "engine" of the

\footnotetext{
${ }^{51}$ K. Ambos, European Criminal Law, Cambridge University Press, 2018, p. 14.

${ }^{52}$ H. Satzger, International and Criminal law, C.H. Beck, Hart, Nomos, second edition 2018, p. 45.

53 Further UE.

${ }^{54}$ H. Satzger, cited work, p. 82.
}

CONSTITUTIONAL NEWS 
development of the European criminal normative framework. The CJEU pronounced a number of benchmark decisions in this area, in which it ruled on the obligations of states in the field of criminal law, invoking the principles of sincere cooperation, effectiveness, equivalence. Thus, for example, in Case C-105/14 Taricco and others, the CJEU underlined the general obligation of states to provide for effective sanctions, noting that "Article 325 TFEU obliges Member States to fight against illegal activities that harm the financial interests of the Union through measures to discourage fraud and provide effective protection and in particular oblige them to take, in order to combat fraud that infringes the financial interests of the Union, the same measures as those they take to combat fraud affecting their own financial interests (see Judgment Åkerberg Fransson, C-617/10, EU: C: 2013: 105, para. 26 and the case-law cited therein). (...) Although the Member States, of course, have the freedom to choose the applicable sanctions, which may take the form of administrative sanctions, criminal sanctions or a combination of the two, in order to guarantee the collection of the full VAT receipts and, in this way, the protection of the Union's financial interests in accordance with the provisions of Directive 2006/112 and Article 325 TFEU (see Judgment Åkerberg Fransson, C-617/10, EU: C: 2013: 105, para. 34 and the cited case-law), however, criminal sanctions may be indispensable in order to effectively and dissuasively combat certain cases of serious VAT fraud.)" (paragraphs 37 and 39). Moreover, in Case C 612/15, Nikolay Kolev and others, the CJEU noted that "Although the Member States have in this regard the freedom to choose the applicable sanctions, which may take the form of administrative sanctions, criminal sanctions or a combination of the two, however, they must ensure that situations of serious fraud or other serious illegal activity that undermine the Union's financial interests in customs matters are liable to criminal penalties which are effective and dissuasive (see in this regard the Decision of 5 December 2017, MAS and MB, C 42/17, EU: C: 2017: 936, paragraphs 33-35 and the case-law cited, Judgment of 20 March 2018, Menci, C 524/15, EU: C: 2018: 197, para. 20, and Judgment of 2 May 2018, Scialdone, C 574/15, EU: C: 2018: 295, paragraphs 34 and 35). Likewise, Member States must also ensure that the rules of criminal procedure allow effective sanctioning of offenses related to such actions." (Paragraphs 54 and 55). "It is first and foremost the responsibility of the national legislature to take the necessary measures to fulfil these obligations. Thus, it is incumbent on him, if necessary, to amend its regulation and to guarantee that the procedural regime applicable to the prosecution of offenses that harm the financial interests of the Union is not designed so as to present, for reasons inherent to it, a systemic risk of impunity for the facts which constitute such offenses, as well as to ensure the protection of the fundamental rights of the accused persons. In turn, the referring court must also, without waiting for the national regulation in question to be so amended by law or by any other constitutional procedure, to ensure the full effect of the obligations mentioned by interpreting this regulation to the greatest extent possible in the light of Article 325 (1) TFEU, as interpreted by the Court, or, if necessary, leaving the 
mentioned regulation (see, to that effect, Judgment of 8 September 2015, Taricco and Others, C 105/14, EU: C: 2015: 555, para. 49) (paragraphs 65, 66).

We do not intend to develop this theme here, which is much wider and susceptible to a distinct treatment, our intention being only to emphasize the contribution of European law in shaping the national criminal policy and legislation in this field. We therefore retain both the obligations of the legislature in this regard, imposed by the Constitution and the norms of legislative technique for the elaboration of normative acts, as well as of the national courts, and, in this light, their indirect role in shaping the criminal policy.

\section{. Conclusions}

In conclusion, we note that the criminal law is and should be the work of the Parliament, but many other subjects of law competes in its implementation. We have paid a special attention in this regard to the Constitutional Court and the constitutional review, which is one of the most powerful modelling factors of the normative action of the legislature and even of the public policies, as long as they have to be in accordance with the Constitution. The evolutions under this aspect are also felt in the case-law of the Constitutional Court of Romania, in the sense of acquiring a much more complex role of the courts of constitutional jurisdiction ${ }^{55}$, with the consequence of an ever closer connection between criminal law and constitutional law, of transforming the classic debates of criminal law into questions related to the constitutionality field. In Romania, as in other states, the constitutional review is constantly evolving ${ }^{56}$ in this regard, in applying the principle of legality, the quality requirements of the law, and the observance of fundamental rights ${ }^{57}$.

As regards European law, and in particular European Union law, as it has been shown ${ }^{58}$, in a Europe struggling to establish a common market, the differences between

\footnotetext{
${ }^{55}$ In this sense, we underlined in a paper that "The Kelsenian theory of constitutional courts as negative legislatures has suffered over time, now it is accepted that in certain circumstances, constitutional courts can rule as a matter of legislative omissions. Gradually, in the case-law of the Constitutional Court, the distinction between the legislative omissions that have constitutional relevance (and which can be censored by the Constitutional Court on the way of constitutional review) and those that do not have such relevance (and which determine the rejection of the notifications as inadmissible) has crystallized. We also mention the opinions expressed in the specialized doctrine, which shows that in the situation "when the Constitution imposes a positive obligation to regulate the legislature, then the omission to regulate, after the date of adoption of the Constitution, a reasonable term has passed in which the legislature could do so, it constitutes a violation of the Constitution which can affect the fundamental rights and freedoms." (T. Toader, M. Safta, Admissibility guide to the Constitutional Court, Hamangiu Publishing House, Bucharest, 2016).

55 E. Fortis, cited work, p. 718.

${ }^{56}$ E. Fortis, cited work, p. 718.

57 See the French Constitutional Council of 2 March 2004, no.2004-492 DC, Adaptation de la justice aux evolutions de criminalite, apud E. Fortis, cited work, p. 718.

${ }^{58}$ K. Nuotio, cited work, pp. 1115-1138.
}

CONSTITUTIONAL NEWS 
the legal orders of the Member States can be potentially harmful; economic integration must be followed by legal integration, "at least to a point". The approximation of national laws in criminal matters is not an objective per se, but it obviously serves to strengthen mutual trust, which is the basic principle of the EU. We also emphasized on another occasion that, ultimately, the creation of a European criminal law should not only appear as a response to crisis situations, such as escalating terrorism or organized crime, but, above all, as a common regulatory will, an implementation of a common criminal policy.

Regarding the requirements that must comply with the criminal law, we retain consistency, stability, regulation and application within the constitutional parameters. The knowledge, acceptance and compliance with the rules established by the legislature, the achievement of the preventive purpose of the criminal policy is accomplished in time; it is an initiative of construction and education of the whole society. The behaviour of the citizen in respect of the criminal law is hard and long term achieved, so that the instability and the legislative incoherence are all the more critical in this area. Therefore, the quality requirements of the law must be ensured to the highest degree in criminal matters. As a result, in their efforts to amend the legal framework, public authorities must constantly consider the question: do citizens, the recipients of the law, have the opportunity to know and understand immediately and precisely this multitude of regulations in the dynamics of their amendment? Theoretically, the answer is affirmative, starting from the fact that all these regulations are published in the Official Gazette and that no one can invoke the ignorance of the law. However, practically, the answer is negative, especially if we refer to normative acts, such as emergency ordinances, which enter into force on the day of publication.

The practice demonstrates to us that the decisions regarding the legislation, mentioned above, are not yet insured, even if we consider the numerous decisions ascertaining the unconstitutionality. There are many other rules that have not been subjected to constitutional review. Of course, they benefit from the presumption of constitutionality, but this is a relative presumption. Nor should the danger of precisely the codes, meant to guarantee the stability of the legislation, become, as one author has suggested, "increasingly dysfunctional and chaotic", and their size grow excessively. A "mountain" of overlapping legal provisions can only produce inconsistency and uncertainty, the "avalanche of criminal law" which characterizes, in addition, criminal policy in other states, not being able to clarify the field, but to overload it, at the expense of achieving the purpose of the regulations. Likewise, the "rush" in the adoption of norms in this matter can only be harmful to the quality decisions of the legislation. Any amendment of the criminal law must be carefully articulated in accordance with the rules in force.

The stated requirements and risks must be taken into account by all the actors involved in the implementation of the criminal policy, its regulations and enforcement, according to their constitutional competences. As the Constitutional Court holds in one 
of its decisions, "traditionally, constitutional doctrine recognizes the three powers in the State: the legislative power, which creates and amends the law, the executive power, which executes and imposes the law, and the judiciary, which interprets and apply the law. The rule of law presupposes that these powers exercise their prerogatives independently of each other, as their functions must be distinct. In other words, those who create the law should not be involved in its application, those who execute it must not be involved in its creation or interpretation, and those who interpret and apply the law should not be involved in its creation or amendment. Thus, by virtue of the principle of separation of powers, enshrined in Article 1 para. (4) of the Constitution, as well as the provisions of Article 61 para. (1), the Parliament and, by legislative delegation, under the conditions of Article 115 of the Constitution, the Government has the power to establish, amend and repeal legal rules of general application. The courts of law, the Public Ministry and the Superior Council of Magistracy, components of the judicial authority by virtue of Chapter VI, of Title III - The public authorities, from the Constitution of Romania, have the constitutional mission to achieve justice, pursuant to Article 126 (1) of the Fundamental Law, that is to settle, by applying the law, the disputes between the subjects of law regarding the existence, the extension and the exercise of their subjective rights, to represent the general interest of the society and to defend the order of law, in the judicial activity, pursuant to Article 131 (1) of the Constitution, respectively to fulfil the role of guarantor of the independence of justice, according to the constitutional norm contained in Article 134 (4), and by no means a role in the activity of elaborating the normative acts, by participating to the legislative procedure".

Last but not least, we want to underline the component of sincere cooperation in this field, as well as the need for its orientation towards the highest degree of educational, preventive side of criminal policy. The behaviour of observance to the criminal norm, the loyal behaviour to the constitutional values shall be formed in time and it shall not be imposed by the application of the punishment. 